\title{
Heidegger, Technology and Postmodernity
}

\author{
GREGORY BRUCE SMITH* \\ University of Michigan
}

\begin{abstract}
This article presents an overview of Martin Hiedegger's philosophical thinking in regard to technology. Heidegger is a key twenticth century thinker whose work can be compared and contrasted to the more well known thinkers and their insights in regard to modernity. Using Heidegger as a springboard, and locating him in the historical context of modernistic thinkers (which include Machiavelli, Descartes, Bacon, Newton, Hobbes) this article provides a definition of modernity that coheres to historical and present day conceptions; and treats Heidegger's critique of modernity, technology, and metaphysics as a key to understanding conceptions of postmodern political and social life.
\end{abstract}

Modernity began as an idea. We can trace its origin, although perhaps only with imprecision. It was the idea of Machiavelli, Descartes, Bacon, Newton, Hobbes and a host of others. The unprecedented transformations of the modern age are an indication that ideas have consequences. Ancient traditions were left behind in favor of a world that we projected for ourselves as the product of conscious human choice. Freedom, emancipation, liberation and self-determination became the watch-words of the age.

The thinkers who helped launch modernity shared a revulsion at being the pawns of a tradition that was the product of accident rather than choice. They wished to cast from their backs the weight of mores which humanity had carried throughout history like beasts of burden-camels, to use Nietzsche's metaphor.' To use Machiavelli's metaphor, moderns wished to "conquer Fortuna."2 From the beginning the most profound longing of modernity has been to fashion a world that is the product of human choice.

The French Revolution is the quintessential modern act. Ancient traditions, the products of centuries of more or less unconscious trial and error-or Burke's collected wisdom of the ages-were cast off. They were replaced by the consciously constructed Code Napoleon. The exhilaration of freedom, of choosing, of being the product of one's own hand rather than some mysterious "Other"- whether that be God, Nature or blind Fate - that is the modern approach to Reality. Karl Marx gave perfect manifestation to this dream, to live in a human world wherein we overcome alienation

*Direct all correspondence to: Gregory Bruce Smith, Department of Political Science, University of Michigan, 5602 Haven Hall, Ann Arbor, MI 48109-1045. Telephone 313-763-2207.

The Social Science Journal, Volume 28, Number 3, pages 369-389.

Copyright $(\mathcal{C} 1991$ by JAI Press Inc.

All rights of reproduction in any form reserved. ISSN: 0362-3319. 
from our true humanity or "species being." 3 The task of the thinker was to change the world, not merely apprehend and understand it. ${ }^{4}$

Surely the dream is still present and shapes our understanding of ourselves and our place in the world. Yet our faith in human reason and its ability to transform the world has been severely tested by our experiences in the Twentieth Century. We expected Kant's "universal peace;" we got the most barbarous of wars on the greatest scale our species has yet seen. We expected equality; we got the creation of new clites that Marx assured us could not emerge. We expected greater humanity; we got genocide. We expected the dignity of true individuality as the legacy of postrevolutionary freedom; we got the uniformity of mass societies manipulated by fads invented on Madison Avenue and the resultant pop-culture and its monotonous life on the ever agitated treadmill, to borrow and amend a Tocquevillian metaphor. ${ }^{5} \mathrm{We}$ were told that our past was merely the necessary means by which we arrived at our truly human present; but as our past traditions faded we came to feel anomie and rootlessness and longed to reinvigorate our fading customs. ${ }^{6}$ As the rational, secular world we longed for came to pass, we felt alone and longed for new gods, occasionally accepting vulgarized old ones from panderers as better than nothing. At a time when we are supposed to be spontaneous, self-creating beings we see impersonal bureaucracies everywhere, and an ever tightening technological web encompassing us, complete with impending shortages, ecological imbalances, noxious industrial residues, decreased privacy, a shrinking, overpopulated world.

We are left to wonder if these phenomena are the inevitable product of modernity, or merely the ground for impatience and carping on the part of a modernity that has yet to arrive at its telos. If the latter, then more intensified doses of modernity are in order. If the former, then we are forced in the direction of a more radical kind of questioning. With the increasing use of the term "postmodernity" we might suspect that that more radical questioning has begun. Yet the variety of competing uses of this term throws the discussion into almost immediate ambiguity.

\section{POSTMODERNISM}

In contemporary architecture the term "postmodernism" is opposed to, "modernism," the movement that gave us buildings dominated by simple geometrical patterns unadorned and with no attempt to camouflage the structural necessities of the edifice. To these boxy buildings with long, unbroken straight lines postmodernist architecture adds gables, classical columns or other forms borrowed from the past. The result is a unique, if sometimes ugly, pastiche of old forms. But no truly novel forms are created.?

In discussions of postmodernity in the social sciences the term is frequently linked with the concept "post-industrial society." Service industries take precedence over industrial means of generating wealth. Information becomes the major form of "capital" in the new economy. The "new class" sells this new capital in an increasingly global market dominated by computers and satellite information links. A "high tech" consumer society comes into existence. Old urban areas are no longer necessary as a hub where capital, labor, raw materials, industry and commerce come together in the same place. Decentralization and globalization occur simultaneously. 
In philosophy the term "postmodernity" is linked loosely with "poststructuralism." The post-structuralist focuses on the extent to which Reality is constituted by our very acts of trying to use, describe and understand what is. This is true of our own being as well. In attempting to explain Reality we in fact constitute it-whether completely or partially remains an open question. Post-structuralism builds on the notion that Reality is fundamentally malleable, both human and non-human. Since we are not beings with a simple, pre-given structure or nature we cannot do our constituting of Reality consciously or rationally. That would imply a stable, unchanging actor. Hence the modern desire to consciously and rationally reconstitute the world is seen as a chimera. Likewise, any closure, or "end of history," is simultaneously rejected.

As an example, Jacques Derrida's version of deconstructionism argues that all of existence is a text. ${ }^{8}$ In "reading" (i.e., trying to understand) any text we re-write it. This is true whether the text is a book, Nature, a society or ourselves. This is a constant, endless process that cannot be done consciously, at least not with the autonomous self-consciousness prior modernity had posited. Hence we cannot determine an author's intent any more than the original author could. Nor can we ever stop rewriting. We do that by living. There is no human experience per se that is shared by all human beings; everything is a surface that constantly reconstitutes itself in an ongoing play of presence and absence. This is the shared premise of poststructuralist theorists like Derrida, Michel Foucault, Jean Baudrillard or Jacques Lacan.

Without cataloging every discipline where the term postmodernism has become current we can sketch a general postmodernist attitude, style or tone that manifests itself artistically, culturally and pop-culturally. ${ }^{9}$ Throughout postmodernism there is a fascination with the surface. This is conjoined with a perception that all of existence is a humanly constructed surface that has about it the aura of arbitrariness. This leads to an ironic attitude toward life and finally to a form of cynicism. There is a tendency to give in to a mocking superiority, the sense that one knows that nothing is worthy of passion or commitment because everything seemingly solid dissolves upon our approach. As a result, an attitude of indifference, weariness and exhaustion is frequently exuded. From all of this one suspects the existence of a form of evasion, an attitude of avoidance, a blase, unshockable refusal to face up to the terrors that surround one in modern life as well as the general groundlessness of that life (a groundlessness that is blithely admitted).

The fascination with the surface also predictably manifests itself in the characteristic postmodernist sortie through past forms that are combined and juxtaposed in novel and at times purposely bizarre ways. In place of novelty and creation one gets "pastiche, collage, montage." "Postmodernists ransack history for shards because there is no here here; because historical continuity is shattered by the permanent revolution that is [modernity]."10 This provides an explanation for the attitude of indifference and avoidance. We live in a world of abstractions. Particularity dissolves, the concrete world withdraws, we are surrounded by the reign of triviality. Our world is an unworld. Such a situation is also explained by Milan Kundera's phrase "unbearable lightness of being." 11 The postmodernist responds by adopting a stance whereby he/she will not be unduly moved or hurt by the predicament. 
One suspects, therefore, an attitude of waiting without weighing. Postmodernism ensues when one moves beyond the modern faith in progress, reason and the selfconscious will. When the modern faith in man's ability to self-consciously recreate the world comes to be seen as a chimera, and no alternative faith is available, man adopts a defensive posture. A time of waiting occurs; we bide our time. By its very name postmodernism presents itself as a sequel, something that comes after something else. By its very name it designates nothing unique that is explicitly coming. Postmodernism does not present itself as on the way to anything. It is a phenomenon of a post-historical age, passionless and jaded for fear that making do with the presentwhile keeping at a playfully sophisticated and detached distance-is the safest stance that is available.

\section{THE LOGIC OF THE POSTMODERN}

If we are to be resolutely logical in our use of the concept postmodern it should stand for something other than the radicalization or intensification of tendencies that are deeply modern. It must stand for more than achieving the telos of modernity; it must be beyond that telos. And it must stand for more than rearranging the furniture of the past, as with postmodernist architecture, and more generally, postmodernist art and pop-culture, where nothing new is created.

I will argue that postmodernism as we are seeing it manifested in architecture, post-structuralism, the social sciences, discussions of pop culture, etc., is a thoroughly modern phenomenon. It represents the logical outcome or extension of the modern project. I will return to this issue below.

In the interim, I wish to reflect upon what a resolute use of the term postmodern would imply. It will be the contention of this article that postmodernity in a resolutely postmodern sense is what Martin Heidegger attempted to articulate. I will at present bypass the more difficult question of whether he accomplished more than another intensification of modernity. It will also be argued that Heidegger's version of postmodernity can be best approached through his very novel discussion of technology. Confronting that discussion will bring to light the features of modernity Heidegger most wanted to transcend and will provide us with a preliminary working conception of modernity.

According to Heidegger, moderns have adopted an entirely unique stance toward Reality. For medieval thinkers Reality was conceived as ens creatum, the conscious creation of a creator-God who is the highest cause, the ground of all grounds. For the Greeks Reality was that which arises and opens itself, the Greek physis (Nature), thereby coming into presence, i.e., appearing before man. For example, Heidegger argues that for the Greeks "Truth" (alēthéia) is the entire process or event-later designated Ereignis by Heidegger-of coming into unconcealment or presence from out of "concealment." 12 Man in turn opens himself to what self-presences and apprehends it. For premodern thinkers generally, Reality is grounded in something which is other than man. For neither medieval nor Greek thought did that which is present open itself to us and come into Being because man first looks at it. Man can look at or apprehend the world only because something is already present, having come forth from concealment or absence in some more or less mysterious fashion prior to man approaching it. 
According to Heidegger, the distinctively modern relation to Reality (Being) is set in motion by Descartes. For Descartes, if things are to become present in a reliable fashion, they must first be consciously set in place by man. There must be a prior projected plan or methodology which determines what will count as Being and what will not because it is methodologically unreliable.

Something must be consciously stipulated in advance as already known before modern man can fruitfully approach Reality. In modern science the plan or projection that exists first and shapes what will count as having "Being" is a "self-contained system of motion of units of mass related spatio-temporally."13 Such a projected plan secures the object sphere only within the terms of mass and velocity. Any other manifestation of Reality is ignored or dismissed as false and specious (in Heidegger's terminology, it remains concealed, it is "absent," it does not present itself). Thus Nature, understood as physis, as self preserving, is not allowed to present itself and man is denied the possibility of careful observation of that which presents itself, as it presents itself (empeiria). It is in this way that all modern phenomena present themselves. Man treats the world as a consciously created perspective or "picture."

In this way, modern things are set in place or made present-they attain Being-by being set over against us as "object" (gegenstand). It is this understanding of Being that Heidegger wishes to displace. ${ }^{14}$ What counts as Nature or History or any other object sphere must be defined in advance by man's prior projected plan. Once Being is brought before man as "objective" man comes to presence for himself as "subjective," i.e. that which lies before as the ground of all being (hupokeimenon). The world as objective is a consciously projected "picture" of a subject. The modern age is distinctive in that Reality comes to be understand as a picture, as our picture. The modern age is the "Age of the World Picture" in which everything is an object grounded by a subject. ${ }^{15}$

Only in the modern age does the world present itself as a picture. This is Heidegger's understanding of what is distinctive about the modern age. There is no such thing as the medieval world picture or world view, except retrospectively. For medieval thought the world is not the projection of a human subject, but the creation of God, just as for the Greeks Being is self-presenting. Only subjective, modern man thinks he opens Reality for himself.

Only within the modern understanding of Reality is modern science and modern research understandable. Modern science is not primarily distinguished by being more exact than premodern science; it is distinctive in that it conceives of Being in an entirely different way. ${ }^{16}$

Experiment begins with the laying down of a law as a basis. To set up an experiment means to represent or conceive the conditions under which a specific series of motions can be made susceptible of being followed in its necessary progression, i.e., of being controlled in advance by calculation .... Every science is, as research, grounded upon the projection of a circumscribed object sphere and is therefore necessarily a science of individualized character. Every individualized science must, moreover, in the development of its projected plan by means of its methodology, particularize itsclf into specific ficlds of investigation. ${ }^{17}$

The attitude of modern science to Reality is indicative of the modern approach to Reality in general. It is assumed that Reality is not accessible, or not accessible in 
any coherent way, unless it is set up in advance by a consciously projected plan or methodology. Man henceforth consciously decides how everything will present itself. Everything is brought to presence as the "standing over against" of an object that is re-presented in a subject. Man as subject replaces man as apprehender. As a result thought is necessarily transformed into methodology and philosophy is fundamentally reduced to epistemology.

Each object sphere develops its own methodology and epistemology. Science becomes institutionalized by breaking itself up into a variety of specialized fields. The world becomes split up into a multiplicity of object spheres. The unity of the whole is lost. In fact, it comes to be admitted that the whole is in principle unavailable. When modern man looks to find a way to conjoin the various object spheres he eventually turns to cybernetics. ${ }^{18}$ This gives the illusion of unity. But all relation to ontology is lost. In the age of the world picture, we have a situation like that of the blind men and the elephant, except that the blind men constitute the elephant in their attempts to apprehend it. They each constitute it differently. With no ontological foundation, the possibility of a general field theory is an illusion.

Eventually man not only sets about constituting the various object spheres but himself as well. Man decides how everything must henceforth present itself, including himself. Man takes his stand to even himself in the mode of measuring and executing for the purpose of mastery over what is. ${ }^{19}$ Bureaucratic rationality and organizational sophistication become the webs in which modern man inevitably is caught.

As a result, the modern relationship to the world, oneself and others transforms itself into a contest between consciously constructed world views-c.g., feminist versus deconstructionist, Freudian versus Existentialist, Liberal capitalist versus Marxist communist versus Fascist, etc. Life becomes a contest over who gives measure and sets out the parameters of everything that is. Just as politics becomes ideological, personal life becomes devoted to self-definition. And as there is no deeper ground than the subject, there is no basis for the amelioration of disputes among competing world pictures or self pictures that is not agonistic. World wars become inevitable and unavoidable just as does strife between self-constituting groups and individuals. ${ }^{20}$

To support the various pictures or views,

man hrings into play his unlimited power for the calculating, planning and molding of all things. Science as research is an absolutely necessary form of this establishing of self in the world; it is one of the pathways upon which the modern age rages toward fulfillment of its essence, with a velocity unknown to the participants. With this struggle of world views the modern age first enters into the part of its history that is the most decisive and probably the most capable of enduring. ${ }^{21}$

In short, modernity finally arrives at its telos.

The conquest of the world is possible only after it has been transformed into a picture. And only after that transformation are subjectivism and individualism possible. Eventually, we are forced to decide whether our subjectivity exists in the form of an "I" or a "we," as individuals or communities. According to Heidegger, only as "subjects" would it ever dawn on individuals to struggle against the effects of individualism on behalf of the community. Only in fleeing individualism and subjectivism 
would it dawn on man to make the conscious flight into tradition (i.e. back into past traditions that emerged before the world was viewed as a picture and man as a subject). ${ }^{22}$ These are uniquely modern phenomena.

Furthermore, only as subjects would it make sense to believe that we impart "values" to things and then feel the need to debate over whether we do it as individuals or groups (i.e., are all values culturally determined or consciously projected by each individual). Having projected the Being of the object sphere, the subject must then also confer value on its object, an undertaking that Heidegger sees as redundant if one is really following the logic of the subject-object dichotomy. The fact-value dichotomy could only come into existence on the basis of the modern understanding of Being as our projection. According to Heidegger, this would never have dawned on the premodern who primarily apprehends that which brings itself to presence.

Hence according to Heidegger all the novel phenomena of politics and morals, of psychological and historical understanding, of modern epistemology, experimental science and technology that are taken as indicative of modernity are merely surface phenomena that result from our new relationship to all that is. Moderns relate to the world as subjects that must in advance project Being before anything can come to presence as our object. Therefore, we could become truly postmodern only by transcending the attitude whereby we see the world as our picture and ourselves as projecting subject.

Unfortunately, in Heidegger's understanding moderns cannot consciously transcend their age. That would imply that man is still acting as a subject merely projecting a different picture of the world. Neither can we simply go back to the premodern understanding. Both the Greek and medieval understandings differed from the modern, but they contained within them the seeds out of which the modern understanding grew. Hence, according to Heidegger, it is necessary to transcend the entire Western tradition of thinking which he designates as "metaphysical." Heidegger's novel understanding is that modern technology, far from being anti-metaphysical, represents the final stage of the history of metaphysics.

\section{HEIDEGGER AND TECHNOLOGY}

Heidegger argues that the traditional ways of conceiving technology are inadequate. Neither the anthropological view that technology is one form of human activity among many (e.g. including also praxis and theoria), nor the instrumentalist view that technology is a neutral tool, a means to an end that can be calculated and controlled by conscious human direction, grasps the essence of modern technology ${ }^{23}$ For Heidegger, technology is a distinctive way of revealing or relating to Reality. As such it is never simply under conscious human control, for technology's distinctive mode of revealing Reality always stands prior to any conscious act taken on the basis of what is already revealed. And technology cannot be just one among many neutral kinds of behavior in which man engages. As a mode of revealing of Being, it is the most essential behavior of man. For Heidegger, the essence of being human is qua the being who is the site for the revealing of Reality.

For the Greeks, techné is a form of poiésis or making. Techné, in its original Greek signification, brings forth into existence that which does not bring itself forth. For 
the Greeks this is what differentiated it from physis or Nature, which is self-presencing. But modern technology constructs a novel relation between techné and physis. The modern understanding of techné is not differentiated from premodern techné by its greater power or precision. It is, according to Heidegger, qualitatively different. Modern technology is a revealing that is a "challenging forth" rather than any simple apprehending or combining of natural givens in novel ways. It sets upon Nature, unlocks it, exposes it, and challenges it to do man's bidding. Matter is transformed from its natural state and kept in the ready in its new state until it is needed by modern industry. For example, matter is transformed into energy which is stored and kept "standing by" for future use, manipulation and ordering. Modern technology takes what is, transforms it and keeps it in "standing reserve" until it is wanted. This is what differentiates modern technology for all past poiésis.

All of Reality is transformed into standing reserve (Bestand). That into which Reality is transformed is eventually (as energy) no longer present to man in any way. Reality conceived as standing reserve, as malleable, transformable and capable of being stored in different states than it is found and will eventually be used, reveals Reality to man in a way that is entirely different than as object (Gegenstand), that which stands over against a subject. Now a situation occurs where nothing stands in any sense. The world ceases to have any "otherness" for man; Reality dissolves into a variety of abstractions; nothing is present; there is no here here. Only by initially treating Reality as object can modern science so set upon the world that it can transform it into standing reserve. The irony is that in the process objectivity dissolves completely.

Modern objectification transforms itself into the loss of the world. When this happens, the subject-which initially projected objectivity - no longer has any place to stand. In the account of Being and Time modern man is "everywhere and nowhere." 24 Without its object, a subject no longer has any Being. The lack of a "there" yields what the early Heidegger called inauthenticity, characterized in part by "ambiguity" (as to the where of our existence), "idle talk" (love of the superficial play of surfaces), and an aimless, superficial "curiosity." 25 In the more poetic account of Heidegger's later work, modern man becomes homeless; he loses all rootedness in his native surroundings. ${ }^{26}$ Heidegger is explaining how modern man comes to find himself in a position of groundlessness and rootlessness in the modern age. The world disappears in the objectlessness of standing reserve. Needless to say, Heidegger does not see going back to objectification as an alternative. That revelation of Reality necessarily transforms itself into the more radical technological revelation in which the concrete world dissolves.

First the real presents itself as man's idea, as something that has no self-sufficiency and no capacity to ground itself. This projecting or "enframing" (Gestell) of Nature transforms itself into standing reserve. Reality comes to be understood as primarily determined by such abstract categories as "capital" and "energy." Reality, in being transformed into something abstract, becomes simultaneously something absent. Absence takes precedence over presence in our lives. ${ }^{27}$

Whether we are talking about modern physics or price theory, the technological approach to Reality sets itself up to see how nature responds when challenged and conceptualized theoretically. If the response is "positive," that specific form of challenging is projected as Reality. If not, another attempt is made. But as life becomes 
more abstract and as the world becomes more absent it is difficult to know how to evaluate the competing conceptualizations: what constitutes "positive?" Hence the process of challenging becomes self-generating without any external referent, without rhyme or reason. We get greater and greater technical and organizational sophistication as ends in themselves.

Eventually man too becomes standing reserve, for in the late modern age man is incapable of differentiating himself from the rest of Reality. In the late modern age, there is no way to relate to the essence of the human as something distinctive. Man too is challenged forth-organized rationally and bureaucratically - and calculated as an abstract integer qua productivity, unemployment, demographic shifts, population statistics, etc. Man reveals himself as something maximally useful when properly ordered, arranged and propitiously "sallied forth."

We cannot rebel against this technological revelation of Reality for we ourselves are revealed to ourselves and understood by ourselves in the same way. We have no alternate place to stand whereby we could take up a critical attitude toward the technological revelation of Reality as standing reserve. Consequently, modern technology is no mere instrumentality that man can consciously and rationally control by imposing "values" upon it. We stand within its mode of revealing and cannot stand outside it.

According to Heidegger, if modern man is ever to transcend the technological revelation of Reality, he must first come into a new relation to technology. That means he must cease to understand technology in the traditional fashion. For example, man must cease to see himself as its master and controller and cease to see technology as a neutral tool. Heidegger feels that his novel understanding of technology helps accomplish this new relation.

From out of that new understanding it is possible that a new relationship to Reality can eventually emerge. Until now modern man has seen technology as the benign tool by which he fashioned his emancipation, liheration, equality and humanity. When we cease to see technology in the proto-modern fashion a new relation to technology has begun. When we come to see that we tighten our chains in trying to willfully quit the grips of the modern technological view of Reality we have likewise come into a new relationship to our world.

It is out of these initial transformations of our relation to technology that Heidegger hopes a new revelation of Reality, that is neither objectifying nor based on standing reserve, can emerge. If one properly understands the modern predicament, Heidegger believes it becomes clear that that new understanding or revelation will have to come from unconscious poiésis, not conscious, rational thought. Hence the later Heidegger turns to discussions of the ontological foundations of genuine poetry. For Heidegger, poetry is not just the realm of the production of the beautiful, the arena of aesthetics, but a distinctive mode of revealing Reality that is potentially higher than that of modern technology. Heidegger attempts to reverse the relationship that now exists between poetry and the "hard" disciplines.

When reality is revealed as standing reserve - as something absent and abstract Heidegger argues that man is endangered in his relation to himself and everything that is ${ }^{28}$ Man is cut off from that mysterious ground of all that comes to presence (physis, alétheia). When the technological mode of revealing is in place every other 
possibility is driven out: e.g. art, great statesmanship, religion. Likewise that which reveals itself (Being qua physis) is cut off from man. We become locked in one monolithic mode of relating to Reality which makes impossible the future approach of any others. Stagnation occurs within the monotonous, agitated, ever changing challenging of this monolithic mode of revealing. With no new revelation possible we arrive at the end of History, i.e., the end of novelty. Man's essence as openness to Being in all its possible manifestations is destroyed. Life becomes not only abstract, homeless and worldless, but uniform, monotonous and unchangeable. This is what Heidegger means when he says we have ceased to be historical beings; we have become beings that can no longer create History. All life and all thought at best becomes epigonal. ${ }^{29}$

This is the danger of modern technology. We had to experience this danger before we would be willing to transcend the modern understanding. Furthermore, for Heidegger, overcoming technology ultimately requires transcending the entire Western tradition of metaphysics. Heidegger's novel view is that technology is the final culmination of metaphysics. Hence, we must be open to a new mode of revealing of Reality that is not metaphysical.

Technology forces us to lose our relation to "otherness." We come to see ourselves as the only thing in Reality. We lose our relation to that which is not simply our projection. This had already been prefigured in the metaphysics of Plato. In Heidegger's way of posing the matter, when we realize that "enframing" is the "destining" (deferred ramification) of a previous mode of revealing (the platonic, metaphysical), the "saving power" draws near and sets in motion the possibility of a new, future mode of revealing. ${ }^{30} \mathrm{We}$ open, in short, the possibility of a new, postmodern (which also means post-metaphysical) return to immediacy and the recovery of the Other.

Technology is immune to simple willful control, but it is not immune to another form of revealing. Unfortunately, by the logic of the argument, we cannot will that new mode of revealing; all we can do is prepare for it. Put another way, Heidegger's philosophy can clear the ground; someone else must do the planting. Art and Poetry are what Heidegger designates as the most fecund possibilities.

\section{ON BEING}

According to Heidegger, technology, as the ultimate outcome of the metaphysical mode of thought, emanates from Plato's transformation of the pre-socratic notion of Being as physis and alétheia into Being conceived as eidos and idea. Being, understood as self-emergence into presence, is intimately linked with the possibility of appearance. Being and appearance were intimately linked in the initial, pre-socratic conception of Being. Man was the apprehending being who stood in the presence of that which brings itself to appearance while also remaining in concealment.

Plato built upon this Western understanding of Being which implicates presence. But Plato transformed it by concluding that the realm of appearance was one of shadows, error and falsity. He diminished the status of that which was immediately present to apprehending man. The realm of appearance was reduced to the status of Becoming. Being was transferred to another realm, the realm of the ideas. Being was transformed into an idea. But Being was still understood as presence in the 
Platonic understanding. Being-i.e. the ideas-was immediately present to thought. The realm of the senses, like the realm of appearance, was lowered in status. That which is available to thought came to be seen as more present than that which was available to mere apprehension.

Initially, the realm of the ideas remained something that man merely "gazed" at. The ideas were not seen as constituted by man. But in transforming Being into Idea, Plato paved the way for the modern projecting of Being as man's idea. That in turn made possible the transformation of being into the "object" of a "subject." And that in turn was the prerequisite for the coming into being of modern technology whereby the realm of objectivity is transformed into "standing reserve," that which is not an object, does not appear, and is in no way present.

Plato set in motion the long process by which man lost presence altogether and was expelled from the here and now. Eventually, in the technological conception of Reality, everything that surrounds us simply dissolves. Man came to be a being who had no place, stood nowhere, and was dominated by the abstract and the absent. The complete withdrawal of presence for Heidegger is the same as the withdrawal of "Being," which while never completely present, has nonetheless an appearing aspect. ${ }^{31}$ The complete withdrawal of Being in the modern age is what Heidegger means by nihilism. Being no longer in any way inheres in beings.

Hence, Heidegger's prescription is that we return to the original Western revelation of Being. We return to the point at which Western nihilism commenced. The transcendence of the nihilism of the modern world requires remembrance of the initial Western revelation of Being as a propaedeutic. It does not require simply pasting the East alongside the West as some would have us believe-e.g., Zen plus modern technology. Remembrance is only a propaedeutic. One must strike off from the reappropriated origins, building a new way of revealing Being and man. Heidegger's thinking is not a form of backward looking Romanticism. Heidegger would have us return to the point at which the oblivion of Being began. But he intends to move in an entirely different direction than that taken by the metaphysical tradition. The pre-socratic, Western understanding of Being as physis contains within it unique, non-metaphysical possibilities. At least that is what Heidegger believes.

According to Heidegger, only now is the overturning of metaphysics possible. ${ }^{32}$ The history of the West had to work itself out to the point of greatest danger, "the darkening of the World, " ${ }^{33}$ before a healthy relation to reality could be accomplished. For Heidegger, things in the West have never been quite right. The entire history of the West is the history of the growing alienation from and oblivion of Being. To allow Being to again presence initially involves seeing that there is something Other than man that is not his object. That Other is, however, not fixed or static, and it is not the opposite of appearance. Explaining this difficult notion partially accounts for Heidegger's complicated language and mode of presentation.

According to Heidegger, his novel understanding has never been yet approached. The Greeks saw Being as Other than man, but fixed and determinate. The moderns came to see Being as changeable because it was a product of human projections. Being was changeable but it was man's projection rather than self-subsisting. Heidegger puts the two together in such a way that Being is Other than man, changeable and never completely present. Whether this conception is in fact novel remains a question. 


\section{POETRY AND ART}

In preparing his new conception of reality, Heidegger thinks that he opens the way to the potential, future overcoming of the technological relation to reality that has hegemony in the modern world. Ultimately, however, the actual overcoming cannot, in Heidegger's understanding, be accomplished by philosophy. It will be accomplished by poetry and art. This leads Heidegger to his distinctive discussions of poetry and art. He tries to show that poiésis must be understood as a mode of the revealing of reality and not merely the conscious production of the beautiful. Art does not move primarily in the realm of the aesthetic. The "aesthetic" realm is understood by modern man as the facade man pastes onto his "objects." Art so understood is too easily co-opted by the technological attitude of planning and mastery. It transforms itself into the art industry and mass art. Such art does not reveal the world in any uniquely, non-technological fashion. As a reaction against the mass art industry, most postmodernist art, qua negation, still remains determined by it.

According to Heidegger, true art and poetry reveal reality in a prescientific fashion. In his famous discussion of "the fourfold," Heidegger argues that in our prescientific and pretechnological relation to the world we dwell on the earth, under the sky, before the divinities and beside other mortals.$^{34}$ Earth, Sky, Divine and Mortal together are indictive of a prescientific or phenomenological revelation of things. It is likewise indicative of Heidegger's understanding of how man relates to a world in which he takes the phenomenological realm of appearance seriously. It is further indicative of how Heidegger thinks reality reveals itself when it is not objectified or reduced to standing reserve by the prior conscious projection of a human plan.

Heidegger thinks that art reveals reality in a way that is closer to the original, pre-socratic understanding of Being as alethia and physis, where reality brings itself to stand. Such a relation is important to Heidegger because he has concluded that only within this kind of relation to reality is genuine human dwelling and rootedness possible. "Dwelling" for Heidegger means having around one a world that is familiar, within which man can act with a good conscience and without adopting the detached stance of irony and cynicism. "Dwelling" is the alternative to the rootlessness and homelessness Heidegger attributes to technological world. And true dwelling requires poetry: "Poetically man dwells." 35

Unfortunately, Heidegger's account is complicated by the fact that he sees man as intimately implicated in the process of revealing reality, of bringing it forth into presence out of a prior, mysterious concealment. This is true even of the poetic revelation of reality. Man belongs to the process of unconcealment or coming to presence (later formulated by Heidegger as the "event of appropriation" Ereignis). Man is the "site" where Being presences. Man is a space, place or "there" (as in Da-sein) for thruth (alétheia) to happen. How active man is in this process is never quite clear in Heidegger's work. When man tries willfully and consciously, in the mode of modern technology, to master Being, he fails and closes himself off from the mysterious ontological source.

Since this mysterious source never completely reveals itself as metaphysicians hope, it always remains to some degree concealed and absent. Consequently, for Heidegger the ontological ground is always an Abgrund. But in our time the ground no longer shows itself at all in the things that surround us. This is the basis of modern 
nihilism understood by Heidegger as the dissolution of everything into an abstract and absent "standing reserve." And Being will not reveal itself in a new way until man adopts a new stance to reality.

In a way, it seems man must be active in the Being process. Indeed in the early works Heidegger says that the poets "wrest" Being into presence by their works. ${ }^{36}$ Later Heidegger sees great art as the product of grace. Either way it is the great works of poetry and art that open up and make space for things to reveal themselves. Only after primordial, prescientific space has been opened up for our familiarity and involvment is it possible for man to stand back in an act of Cartesian detachment, abstract from primordial spatiality, and project uniform three dimensionality and quantitative extension. The prescientific revelation of space is always prior to the possibility of enframing. The poets open up the prescientific. In some fashion man must do something first to open the space where things can be present.

Increasingly, the later Heidegger makes it clear that the great works of art are not conscious constructions but acts of inspiration that overwhelm the artist. And this is consistent with any number of accounts of poets and artists that the inspiration for their work comes when it wants and not when they will it. The poets are the conduits for Being to presence.

As early as Being and Time Heidegger makes it clear that his understanding of our primordial relation to the world is one of immersed involvement. We are "naturally" projected outside ourselves, alongside the things in the world with which we are actively involved-whether that be tools, loved ones or the well-being of our nation. Western metaphysical thinking has alienated us from this immediate relation to reality. Genuine art and poetry-seen not as merely aesthetic but as modes of revealing the truth-can re-establish this relation in some new post-metaphysical fashion. Heidegger tries to elevate the ontological status of poetry and art as more primal than modern science and technology. He also tries to show how they differ from the conscious projecting of modern technology. Again, the difficulty in doing this helps account for Heidegger's formidable way of writing.

Poetry and art are the ontologically most primordial modes of revealing because in a genuine relation to reality, experience presents itself in "wholes." This is not the case in metaphysical thought according to Heidegger. For example, Aristotle presented reality as an underlying substance to which characteristics are attached (qua accidents). For Kant reality is the unity of the manifold. For Plato it is matter plus form. Heidegger argues that the unit of primordial experience is always something whole like a rainstorm rather than an ensemble of sensations and/or thoughts. In another example, he observes that when working we are absorbed in our project, one with the hammer, the wood and the immediate environs. Only poiésis can reveal the world in this primordial fashion and simultaneously bind man to it. In doing so it brings a distinctive historical world to pass and binds us to a particular part of the earth. In a primordial relation to reality we are always autochthonous. And for Heidegger all human well-being and greatness requires such limit (peras) and rootedness. No rootless, global, cosmopolitan civilization can allow Being to presence in things.

Heidegger's account is also complicated by the fact that in his understanding primary Nature is never a home for man. In Heidegger's thought there is absolutely no Romanticist longing to go back to a simpler, more natural, earlier form of human 
existence. Only when art opens a distinct historical World for man is he bound to the "earth" (a phenomenological category for Heidegger) in a "sheltered" fashion. Primary Nature is not a home for man until it is opened up and revealed as part of a human world ${ }^{37}$ Plants and animals, and the rest of the merely natural realm, have no world. They are linked to their surroundings by covert bonds that cannot change. Not so with man. Earth, Sky, Mortal and Divine are only opened for man in an historical World. Yet the category World cannot become a product of objectification. It cannot be consciously willed and set in place as a Wellanschauung. Like Being itself, the World must remain absent and concealed from everyday experience. When it becomes present to us it is because it has lost its force, become moribund in revealing the world and become a mmere object of detached contemplation by historians. And, Heidegger asserts, no world is acceptable which destroys the Earth and its sel-revealing rhythms and its self-subsistence and self-concealing ground.

Each new, genuine work of art brings with it a new revelation of reality, a new presencing of "Being." There is a ground but it is not static, and to come to presence it needs man; it works through man's infinite variety of ways of revealing reality. With a new work, everyting hitherto existing becomes in a way an unbeing, unable to continue to be revelatory. For example, the Parthenon is not available to us as it was to the Greeks, and it does not now open up or reveal the reality that surrounds it as it did for the Greeks. If Being is linked with the idea of "that which comes to be revealed," thereby coming to presence or appearance, then genuine works of art bring a change of "Being." 38

In the realm of art, linguistic works have a privileged position. In fact, according to Heidegger, only in naming and saying are things first brought to presence. ${ }^{39}$ Where there is no language reality is not really available to man. At the very least, without language man would have no truly human existence. There is no truly human or interesting prelinguistic relation to mere primary Nature that is available to man. In his essence, man is not a natural being.

Poetry takes primacy among the arts. Further, true poetry is always an act of founding for a distinct group in a distinct place. Language is never universal. Hence "wherever art happens... history either begins or starts over again." 40 The task of thinking in our time, according to Heidegger, is to clear the way for such poets, legitimize their work as a form of truth, and wait. Philosophy understood as metaphysics, science or technology without poetry is always inadequate, always eventually leaves man with no here and now, no world; i.e., they lead to nihilism. "Poetically Man Dwells on the Earth." We either dwell poetically — that is prescientifically_or we fall out of Being and into nihilism.

\section{POST-METAPHYSICAL THINKING}

In a future world, freed from the technological revelation of reality, a new kind of post-metaphysical thinking will be possible. That new thinking is designated by Heidegger with the term Gelassenheit, usually translated as "releasement toward things." Heidegger also designates it as "meditative thinking" as opposed to the "calculative thinking" of modern technology. But it is only possible after poets have opened a space for the revelation of things in a new way; since the poets are not 
self-conscious actors, that means only after Being has itself granted a new mode of revealing using a poet as its site.

Again, it must be noted that there is a tension that always is to be found in Heidegger's thought both before and after 1935.41 The appropriate relation to the world is as alétheia and physis, as Other and self-revealing. But Nature does not initially have an open space until the poet provides it. The question is always, how prominent is man's position in the process by which new Worlds come to pass? The tension is resolved in the later Heidegger's thought as much in favor of the Other as is possible, given that man is always the site where presence comes to pass. At the very least, man must assume an appropriate stance toward Reality before anything new can be revealed through him. Nevertheless, thought is always the thought of Being itself. The poets are nothing but the conduit for Being; they are not autonomous, self-conscious actors.

For Heidegger, meditative thinking "contemplates the meaning that reigns in everything that is." ${ }^{77}$ We meditate on what is closest and concerns us most. In this stance toward Reality we cease to calculate and manipulate reality. We are "released" from willful calculation, a "releasement toward things." Initially this will be a releasement toward the things created by technology. But we will be related to them in a new way. There will occur an awe and wonder that they are there at all. We will be led toward reflection on the essence of our historical existence. We will come to ask the new question: "Why and how are such things here at all?"

In the process we will be led toward "the mystery." In Heidegger's terms, Gelassenheit consists of "releasement toward things" and "openness to the mystery." This openness to the mystery is that which is most distinctively post-metaphysical in Heidegger's thought. Metaphysics thinks only that which is already present. It thinks Being as total presence. It also thinks Being as a totally graspable ground. It thinks being as causative, totally present ground. ${ }^{43}$ The new thinking will think its way toward reflecting on the very possibility of presence. According to Heidegger, presence is dependent on a prior opening. "That" which is absent is responsible, in a mysterious way, for the opening that makes presence possible. "It gives" (es gibt) the possibility of presence through the poets. The new thinking will think "Difference" rather than only presence. In other words, it will think both presence and absence. It will think about that absent source which grants the possibility of presence while simultaneously holding itself back in "concealment." "Being," "the mysterious," simultaneously reveals and conceals itself. Absence can never be calculated and dominated in the technological fashion of enframing.

The new thinking will think its way toward the mysterious Abgrund that can never be entirely present, which grants the possibility of presence for the things that man can apprehend. The new thinking will try to think the ongoing process by which mysterious Being both reveals and conceals itself, and reveals itself in a series of historically unique ways. The new thought will, therefore, think the History of Being (Seinsgeschichte). It should be clear why Heidegger thinks he must adopt a novel terminology to describe this new thinking and its object. Whether non-metaphysical speech is possible is another question.

Since the ultimate, mysterious, Abgrund never reveals itself completely, it can never be reduced to metaphysical, representational thinking. Like the God of the Old 
Testament, we will be forbidden to have any "pictures" or images of it. Just as Yahweh describes itself cryptically as "I am that I am," Heidegger describes the mysterious object of future thought as "it," the it that "gives." 44 What it gives or grants is presence. Hence this explains Heidegger's fascination with the German phrases es gibt, which means both "it gives" and "there is." "Thereness" for Heidegger always denotes having a place, which is the prequisite for being present. That is why man is defined as Da-sein, a being that is ontologically a "there." To lose that therencss is to threaten man's essence.

In the modern world, thinking has been reduced to "theory," where consciously constructed operational models become dominant. For Heidegger, such thinking has no ontological foundation. The new thinking will contemplate a self-revealing Other. It will contemplate the mysterious relation of presence and absence. It will think presence and absence as a self-revealing whole. It will be a thinking about the mystery of existence. It will reappropriate a relation to Reality the Greeks designated by the term thaumazein. Awe and wonder will replace the illusion of technical competence. This is the new thinking that will replace the conscious technological "steering of the possible planning of the arrangement of human labor."45

Precisely what the concrete political and moral ramifications of approaching Reality in this new way would be, Heidegger does not say. To do so would, in his mind, be a metaphysical projection of the future. That is the mode of thinking he is trying to transcend.

\section{CONCLUSIONS}

What does Heidegger have to add to our discussion of the possibility of postmodernity, understood in the resolute sense advanced above? If we work within the perspective of Heidegger's thought, postmodernism in its many contemporary manifestations is anything but postmodern. Postmodernism is a logical outcome of modernity. For example, "post-industrial society" represents the very telos of modernity It is Marx's post-historical world, the product of human creation which is no longer dependent on the rhythms of nature, where numbing manual labor is reduced to a minimum. "Postindustrial" society is the very incarnation of the Rationalist/Enlightenment dream.

Post-modernism in philosophy is an extension of Nietzsche's altogether modern thought which culminates in the observation that all of life is interpretation grounded in the will to will. "Poststructuralism" is primarily Nietzsche shorn of the selfconscious will to will. ${ }^{46}$ And Nietzsche's thought is just an intensification of Hobbes' nominalism: i.e., "we know only what we make."

It could also be asserted that poststructuralism is just an intense form of modernity's anti-nature animus. ${ }^{47}$ If there is a fixed and given Nature then the modern desire to reshape the world is radically limited. Therefore, modernity set out to demonstrate the fluidity and malleability of nature and in the end made it dissolve completely. When Machiavelli set out to conquer Fortuna, he built on the notion that Nature could be conceived as Accident or Chance rather than Necessity. Hobbes and Locke wished to quit the state of nature because as they presented it it was a state inimical to the good of man-another version of the anti-nature animus. Likewise, Kant opposed the realm of freedom to the realm of nature. The realm of freedom was 
where our true humanity was to be worked out. Hegel showed how the realm of freedom, the human, geistliche realm, necessarily would come to hegemony over the natural. Marx's communist society presupposed the complete victory of man over nature, technologically and spiritually. "Post-structuralism" merely intensifies modernity's anti-nature animus.

That nothing new is coming into being, as indicated in postmodernist architecture and popular culture, that modern man has lost his here and now, is the result of what Heidegger calls Enframing, our belief we can recreate the world as our "picture." To transcend modernity, to arrive at something genuinely post-modern, one would have to transcend the attitude that turns the world into our projection. We would have to quit the attitude that it is incumbent upon us to continuously create ourselves and the world de novo. This transcendence is what Heidegger attempted. Whether Heidegger himsclf transcends modernity is a question that will have to be deferred to another time. ${ }^{48}$

Heidegger's position in a possible move to postmodernity is to be found in the fact that he has put into words a powerful, novel understanding. That understanding will have consequences. Heidegger has made it impossible to simply relate to the modern world in the same fashion that we have in the past. Others have trod a similar path, but none have articulated their understanding with the same force and comprehensiveness as Heidegger. Henceforth, no serious person will be able simply to ignore the Heideggerian critique.

The modern world comes complete with its own distinctive view of Reality, history, politics and morals. Technology, liberation, individualism, progress, subjectivism, democracy, etc., represent an ensemble of ideas that are indicative of the modern understanding. Those ideas are linked; to begin to question any of the parts is to call into question the whole. Heidegger undertakes that questioning in a powerful way. What he has said - and hence unleashed-can never again be unsaid. The danger is that in transcending the features of late modern life that are the ground for significant dissatisfaction, we run the risk of throwing the baby out with the bath water. The baby in this case consists of modern democratic political institutions, individual freedoms and emancipation from numbing labor and drudgery. Can we transcend increasing technological and organizational domination and a growing cynicism, rootlessness and worldlessness without losing what is valuable?

In the modern understanding, modern technology has been depicted as a benign tool that makes our liberation from Nature feasible, thereby making our political equality a possibility, our self-determining individualism conceivable, mass democracy a reality. By presenting technology as a danger-and again, Heidegger is not alone in this-and subjectivism as metaphysical, one presents a new understanding that reveals in a new way. As a result we are forced to take a new relation to it. That new relation will have different ramifications than the one that saw technology as a benign instrumentality that is philosophically and political neutral, and masterable by autonomous "subjects." Thinking the essence of modernity as technological, and technology as Enframing, is a new way of viewing realty. Changes in thought go forward first. By radically questioning, and probably negating, the legitimacy of a previous mode of thought a whole train of consequences is set in motion. Precisely what those consequences will be can never be entirely predictable. Thought does not have any one-to-one causal relationship to concrete changes. Nonetheless, it surely has ramifications. 
Heidegger rethinks technology, as something different than neutral tool, friend, saviour, ground of freedom, and under conscious human control. Heidegger also rethinks our relation to History. Unlike the modern understanding, for Heidegger, History is not the progressive unfolding of self-conscious freedom but rather the unfolding of our alienation from the world, i.e., nihilism. On an equally fundamental level Heidegger rethinks the relation between metaphysics and technology. No longer is metaphysics seen as the alternative to or enemy of modern science and technology; technology is now metaphysics carried to its logical conclusion. Heidegger depicts metaphysics not as traditionally understood, as thinking about the transcendent - as the meta might lead one to believe-but as an extension of the understanding of Being as presence. The point is that after core ideas-frequently adopted unconsciously - of the modern age have been questioned as radically and fundamentally as Heidegger does, it is impossible to relate to modernity in the same naive way again. Even in trying to prop up modernity and re-establish it, we will be related to modernity in a novel fashion. For example, in the past it was never necessary to re-establish modernity. This new relation to modernity, and Reality more generally, will have consequences. Again, even in trying to confront and transcend Heidegger, Heidegger will have reshaped the debate. Thereby, he has changed the parameters of all future discussion.

It is impossible to know in advance precisely what Heidegger's influence will be. And that is Heidegger's point. Once one calls technology into question as the only legitimate mode of revealing, one hopes Reality will eventually be revealed in some mysterious, unpredictable new way. That is what Heidegger means when he talks cryptically about a new revelation of Being. Heidegger is being genuine when he claims he does not know what that revelation will be.

It is impossible to know what to call a future age marked by a new relation to Reality, one that is no longer modern. Ages are only designated after the fact. The "middle ages" could not be middle until a third age had appeared that could, along with classical antiquity, act as the second bookend. To explain what postmodernity would be like in non-negative, concrete terms would require us to have already invented it and be living within it. To consciously invent and project a future is precisely the modern relation to Reality. In consciously projecting futures we reproduce modernity.

Something truly postmodern would have to come into being on its own. But Heidegger is correct in thinking that one can adopt a new non-modern stance toward modernity. We begin to transcend an age by beginning to see it in a different light than it has traditionally depicted itself. That means in the case of modernity that we cease to see modernity as the peak of human experience, as the height of all times, as the manifestation of everything good and nothing bad, as an end beyond which only retrogression is conceivable. Modernity has pictured itself eschatologically as representing the telos of human striving. When we stand outside that perception of modernity we have already adopted a new stance to Reality. Modernity's own selfconception absolutely implies the eventual end of history. If we open ourselves to the possibility of novel futures we are already moving beyond modernity.

The modern impasse to which Heidegger's thought points, and which postmodernism corroborates, is one where man becomes worldless and loses his here and now. Nothing new comes into being and man sees himself as trapped in some in-between 
time and adopts a cynical, ironic relation to Reality as a result. Man comes to see nothing in Reality but himself, and becomes enervated and exhausted by that realization. Heidegger's prescription is that we must recover the Other. But we must not conceive the Other as "object." Likewise we must not relate to ourselves as projecting "subject." Heidegger proposes an understanding in which the other is self-presencing and man is the site where that presencing occurs.

Likewise Heidegger's understanding sees man as linked fundamentally to a mysterious ground from which he alienates himself only at his own peril. Further, Reality can, therefore, never be exhaustively or discursively presented in its totality (a conclusion many contemporary theoretical physicists on the cutting edge may be beginning to admit as well). This is a different orientation to Reality than the modern, technological orientation. ${ }^{49}$

Every civilization has its own distinctive view of man, Reality and the relation between the two. Our civilization is technological. That technological understanding threatens to become global, making any alternatives impossible. Heidegger offers an alternative. A civilization grounded in the way Heidegger proposes will understand how human existence stretches into the mysterious.

Heidegger presents a critique of modernity we cannot simply ignore or circumvent. He opens a path to a new way of thinking. But perhaps he goes too far. Heidegger's understanding of poetry may remain thoroughly modern: e.g., it remains a form of creation, whereas for premodernity poetry was seen as imitation. In overcoming subjectivism and Enframing need we lose modern individual freedoms? In viewing the modern relation to Reality as unique, must we derive it necessarily from Greek Antiquity? In recovering a notion of the World as self-presenting Other must we lose democratic political life? In recognizing the possibility for fundamental change must we accept that everything, including the mysterious ground itself, changes? It is possible to accept Heidegger's critique of modernity without accepting everything in his teaching.

I would argue that recovery of a ground for our existence in physis, self-presenting otherness, implies that something does not change. The existence of an increasingly global, technological civilization forces us to realize some things do change. Those who think nothing changes - few and far between in our age-and those who think everything changes - to be found on every street corner-never have an incentive to enter into the truly fundamental and necessary investigations. One thing that does not change is the need for a healthy humanity to engage in fundamental thinking rather than giving itself over exclusively to instrumental rationality-about the nature of man and the world. Modern technological civilization tends to obliterate that fundamental thinking. Fundamental thinking represents a point of departure. Fundamental thinking always has ramifications.

I conclude with a suggestion: Perhaps modern political life could be regrounded upon a non-modern notion of Reality qua physis, self-presenting Other. That would represent a novel synthesis that was neither modern nor premodern. It would have a right to be called post-modern. To be completely explicit, a synthesis could be fashioned that combines Heidegger's critique of technological modernity, the Greek understanding of physis and modern political institutions. That synthesis would meet our requirements for an alternative that was resolutely post-modern..$^{50}$ 


\section{NOTES}

1. cf Friedrich Nietzsche, "On the Three Metamorphoses," in Thus Spoke Zarathustra, in The Portable Nietzsche, trans. Walter Kaufmann. (New York: Penguin Books, 1980), p. 137.

2. cf Nicollo Machiavelli, The Prince, trans. Harvey Mansfield. (Chicago: Univ. of Chicago Press, 1985), Chapter 25, pp. 98-101.

3. Karl Marx, "Economic and Philosophic Manuscripts of 1844," in The Marx and Engels Reader, edited by Robert C. Tucker. (New York: W.W. Norton Co., 1978), pp. 70-81, especially p. 75 .

4. Marx, "Theses on Feuerback," in Marx/Engels Reader, p. 145.

5. Alexis de Tocqueville, "How the Aspect of the Society in the U.S. is at Once Agitated and Monotonous," in Democracy in America, trans. George Lawrence. (Garden City: Anchor Books, 1969), pp. 614-616.

6. For a particularly vivid depiction of this phenomena see Milan Kundera, The Joke. (New York: Penguin Books, 1987), pp. 110-123, and especially pp. 45, 111, 116.

7. For a valuable philosophical discussion of modern architecture see David Kolb, Postmodern Sophistications: Philosophy, Architecture and Tradition, (Chicago: Univ. of Chicago Press, 1990). For a different view, see also Steven Connor, "Postmodernism in Architecture and the Visual Arts," in Postmodernist Culture: An Introduction to Theories of the Contemporary, (New York: Basil Blackwell, 1989).

8. On Deconstructionism and Jacques Derrida see my "Cacaphony or Silence: Derrida's Deconstructionism and the Possibility of Political Philosophy," in Political Science Reviewer, Vol. XVIII, Fall 1988, pp. 127-162.

9. See Todd Gitlin's beautifully written and whimsical essay "Postmodernism: Roots and Politics," in Dissent, Winter 1989.

10. Gitlin, Dissent, p. 103.

11. Milan Kundera, of The Unbearable Lightness of Being. (New York: Harper and Row, 1984).

12. See Martin Heidegger, "Age of the World Picture," in The Question Concerning Technology: And Other Essays, trans. William Lovitt. (New York: Harper and Row, 1977) pp. 131,147 . I cannot here go into the complications presented by Heidegger's use of the concept "Being." From the beginning he tried to differentiate his understanding from the traditional usages. At one time, "Being" was used for the entire process by which some absent source sends forth presence yet never itself presences completely. At other time he flirted with using "Being" to designate only the concealed or absent source. Eventually he experimented with (under erasure), and finally he decided to jettison the term as unworkable and overly laden with traditional metaphysical connotations. I will use "Being" in the earlier Heideggerian sense encompassing both what is present and absent, that which reveals itself in appearance and holds itself back in concealment.

13. Heidegger, "Age," p. 119.

14. For modern man, Being is that which is completely present as "object." The absent, the self-concealing source of presence is ignored. Heidegger tries to incorporate this other aspect into his concept of Being, and after he drops the term, into his concept Ereignis. I hope to return to this issue in a forthcoming work, Between Eternities: Nietzsche, Heidegger and the Possibility of Post-Modern Political Philosophy.

15. Heidegger, "Age," pp. 126-131.

16. Heidegger, "Age," p. 122.

17. Heidegger, "Age," pp. 121-123.

18. Heidegger, "The End of Philosophy and the Task of Thinking," in On Time and Being, trans. Joan Stambaugh. (New York: Harper \& Row, 1972), pp. 57, 59. 
19. "Heidegger, "Age," p. 132.

20. Heidegger, Introduction to Metaphysics. (New Haven: Yale University Press, 1959), see pp. 134-135. See also Heidegger, "Overcoming Metaphysics," in The End of Philosophy, trans. Joan Stambaugh. (New York, Harper \& Row, 1973), pp. 103-104.

21. Heidegger, "Age," p. 135.

22. Heidegger, "Age," p. 133.

23. Heidegger, "Question Concerning Technology," in Question, pp. 4-6.

24. Heidegger, Being and Time, trans. John Macquarrie and Edward Robinson. (New York: Harper \& Row, 1962), p. 222.

25. Heidegger, Being and Time, pp. 211-224.

26. It should be clear that Heidegger's discussion of homelessness and rootlessness on this level has nothing particularly in common with the historical rootedness of the German Reich, or any other historical Volk.

27. For a very concrete and striking presentation of this phenomenon see George Steiner, Real Presences. (Chicago: Univ. of Chicago Press, 1989). See especially the third chapter, "Presences," pp. 135-232.

28. Heidegger, "Question," p. 27.

29. Heidegger, "The End of Philosophy," 11 p. 57.

30. Heidegger, "Question," p. 30.

31. See Endnote 12 on the complications involved in Heidegger's use of the concept "Being."

32. Heidegger, "The Turning," in Question, p. 43.

33. Heidegger, Introduction to Metaphysics, pp. 38, 45, 62. .PA

34. Heidegger, "Building, Dwelling, Thinking," in Poetry, Language, Thought, trans. Albert Hofstader. (New York: Harper and Row, 1971), pp. 148-151.

35. Heidegger, "Poetically Man Dwells," in PLT, pp. 211-229.

36. Heidegger, Introduction to Metaphysics, cf pp. 51-52, 121, 126, 137, 147.

37. Heidegger, "Origin," in PLT, pp. 53-55.

38. Heidegger, "Origin," in $P L T$, p. 72.

39. Heidegger, "Origin," in $P L T$, p. 72.

40. Heidegger, "Origin," in $P L T$, p. 77.

41. For our purposes there is no need to pause here for a discussion of the transformation of Heidegger's thought from his "early" to "middle" to "late" periods. It can be asserted that throughout his work, using different modes of speech, Heidegger tried to articulate a new non-metaphysical form of thinking, and also articulate a prescientific, phenomenological relation to Reality.

42. Heidegger, Discourse on Thinking, (translation of the German text Gelassenheit), trans. by John M. Anderson and E. Hans Freund. (New York: Harper \& Row, 1966); see p. 46.

43. Heidegger, "The End of Philosophy," p. 56.

44. Heidegger, "On Time and Being," in OTB, pp. 6-22.

45. Heidegger, "The End of Philosophy," p. 56.

46. See "Cacaphony or Silence," especially pp. 130-134 and 153-162.

47. See "Cacaphony or Silence," pp. 153-162, expecially p. 156.

48. I hope to return to this issue in a forthcoming essay, "Heidegger's Postmodern Politics." In the last analysis, I believe Heidegger remains a modern thinker, albeit one who has consciously moved away from the general, individualistic, democratic, egalitarian and cosmopolitan political and moral components of modernity.

49. While this issue cannot be pursued here, I think Heidegger's critique of modernity could be accepted while rejecting his view that Greek antiquity is the basis of techno-modernity. This later understanding would also represent a new relation to modernity.

50. See my Between Eternities. 